\title{
Diagenesis influencing the porosity of Upper Jurassic reservoir sandstones, Danish North Sea
}

\author{
Rikke Weibel and Nynke Keulen
}

Upper Jurassic quartz-rich sandstones in the North Sea Basin are important reservoir rocks for oil and gas, and one of the latest discoveries of oil in the Danish sector was made in the area of the Hejre wells that penetrated such sediments (Fig. 1). The reservoir properties of sandstones are strongly influenced by diagenetic alteration, i.e. the mineralogical changes that take place during burial of the sediments. The diagenetic features depend on the source area, depositional setting, facies architecture and burial history of the sediment. The major diagenetic features influencing porosity in Upper Jurassic reservoir sandstones are feldspar dissolution and precipitation, preci-pitation of illite, calcite and quartz, and quartz stylolite formation. With regard to the Upper Jurassic sandstones in the Danish sector of the North Sea, the important question is: how can porosity be preserved in sediments buried at depths of more than $5 \mathrm{~km}$ ?

The Hejre-2 well penetrated the Upper Jurassic sediments (Fig. 2) before reaching pre-Upper Jurassic volcaniclastic conglomerates. The diagenetic features were studied in thin sections of core samples with traditional petrographic techniques using transmitted light microscopy supplemented by scanning electron microscopy (SEM) of rock chips and thin sections.

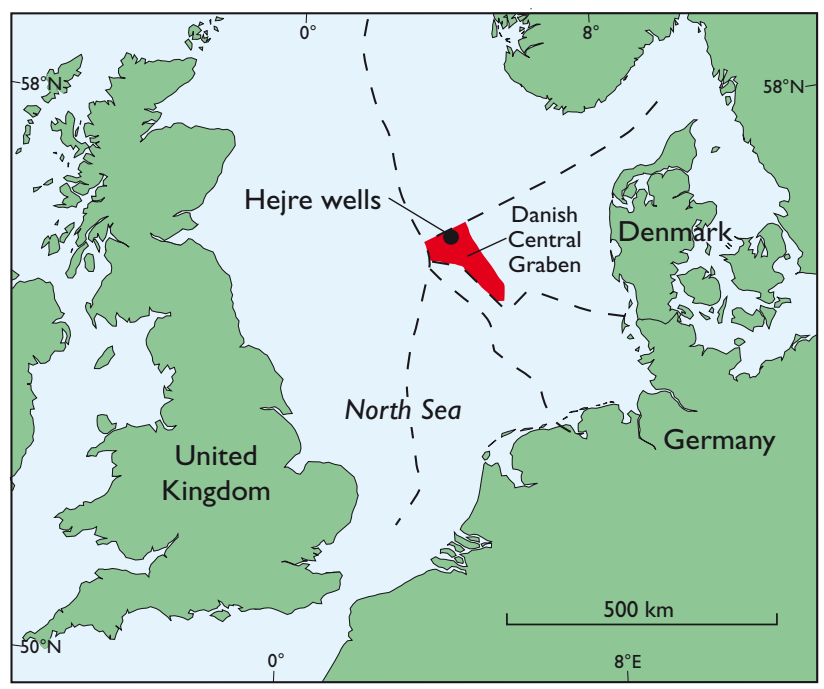

Fig. 1. Sketch map of the North Sea region showing the location of the Hejre wells. The dashed lines show the borders between the national sectors.

\section{Feldspar dissolution and precipitation}

Previous studies of feldspar diagenesis have generally focused on the albitisation of K-feldspar, the dissolution and replacement of plagioclase with clay at deep burial depths, and their importance for the generation of secondary porosity (e.g. Surdam et al. 1984; Bjørlykke et al. 1992). Recent investigations show that the formation of feldspar overgrowths may also be a significant early diagenetic phenomenon (Lee \& Parsons 2003). Early diagenetic authigenic K-feldspar has also played an important role in the Upper Jurassic sandstones investigated here, although the volume of precipitated material is not nearly as high as the succeeding calcite and quartz cementation.

Detrital feldspar, and notably K-feldspar, is a common constituent of Upper Jurassic sediments. Authigenic Kfeldspar may have formed during early diagenesis, but is now mainly preserved in calcite-cemented parts of the sandstones, where it forms overgrowths on detrital K-feldspar, perthite and albite grains (Fig. 3A, B). Authigenic K-feldspar is com-

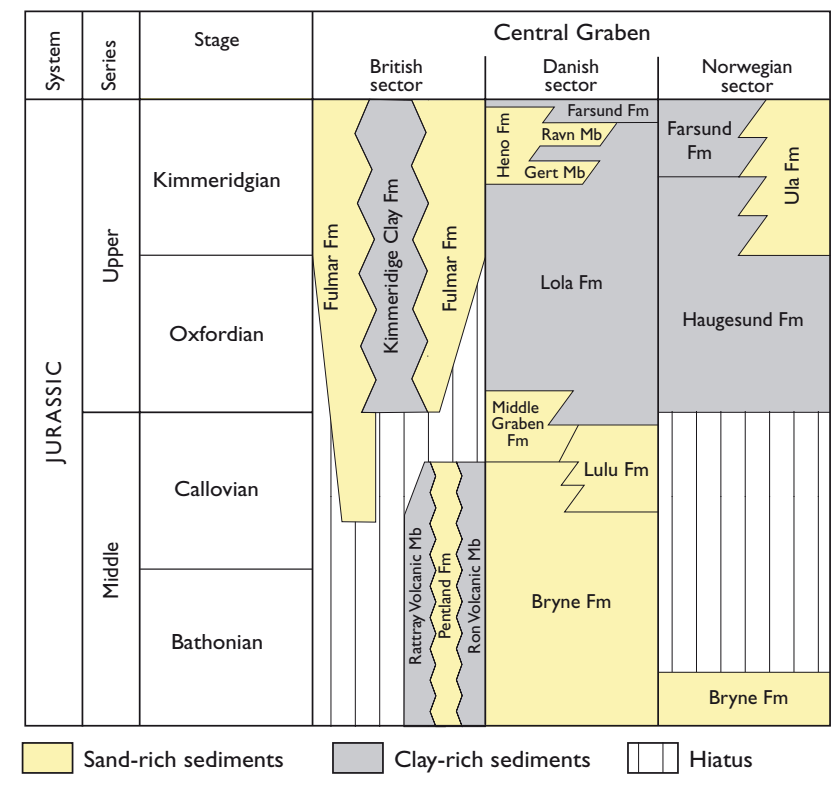

Fig. 2. Middle and Upper Jurassic lithostratigraphy of the British, Danish and Norwegian sectors of the Central Graben in the North Sea. The Hejre-2 well penetrated the Farsund Formation, the Ravn Member of the Heno Formation, the Lola Formation and the Gert Member of the Heno Formation. Simplified after Johannesen et al. (2003) and Michelsen et al. (2003). 

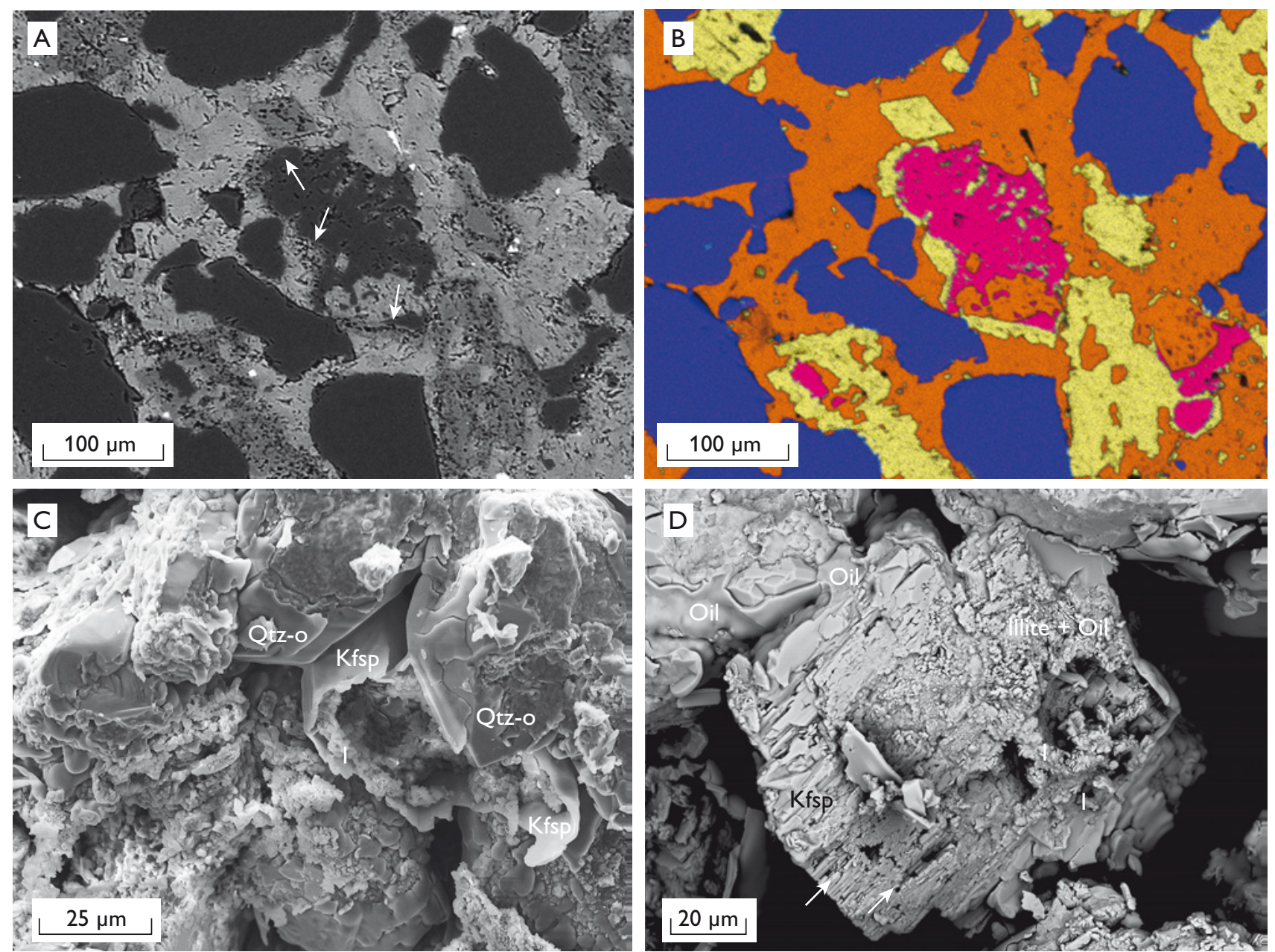

Fig. 3. Images showing diagenetic alteration of feldspars in Upper Jurassic sandstones that resulted in both reduction and increase of porosity. A Abundant detrital K-feldspar and K-feldspar overgrowths (arrows) on detrital albite in calcite-cemented parts of the sandstones. Back-scattered electron SEM image. B: Combined element maps of the area shown in Fig. 3A. Orange, calcium; yellow, potassium; pink, sodium; blue, quartz. C: K-feldspar overgrowths (Kfsp) most likely formed on an original plagioclase grain prior to its dissolution and replacement by illite (I) during which substantial secondary porosity was created. Subsequent quartz overgrowths (Qtz-o) and compression may have reduced this porosity. Secondary electron SEM image. D: Detrital K-feldspar (Kfsp) partly dissolved (white arrows) and replaced by illite (I). Some oil droplets (Oil) can be observed. Secondary electron SEM image.

mon in the vicinity of K-bearing clay-rich intervals and in the sandstone immediately overlying volcaniclastic conglomerates.

Element mapping of the calcite-cemented parts of the sandstones shows the volumetric importance of the early authigenic K-feldspar phase (Fig. 3B). The marine Upper Jurassic sediments (Johannessen 2003) are expected to have had relatively high concentrations of potassium in the original pore fluids, in the K-feldspar stability field (e.g. Worden $\&$ Morad 2000). However, the large proportions of authigenic K-feldspar associated with clay-rich intervals and the underlying volcaniclastic conglomerates could indicate an additional external supply of potassium. The volcaniclastic conglomerates have a very high $\mathrm{K}$-content and must originate from a potassic alkaline volcanic source. Lee \& Parsons (2003) found exceptionally high proportions of sanidine crypto- perthites in the Upper Jurassic Humber Group, inferred to have an ultra-potassic volcanic source. Potassic volcanic sources of Early and Middle Jurassic (Furnes et al. 1982) or Permian age (Aghabawa 1993) are present in the North Sea area, but a determination of the age and location of the actual volcanic source of potassium for the Upper Jurassic reservoir sandstones require further investigations.

Remnants of albite grains are only preserved in the calcitecemented parts of the sandstones, whereas more calcium-rich plagioclase detrital grains are almost completely lacking in the sandstones. These parts of the sandstone are instead characterised by K-feldspar overgrowths around voids of approximately the size of average detrital grains (Fig. 3C). These voids are often partly filled with illite and occasionally authigenic quartz. The K-feldspar overgrowths presumably precipi- 
tated around detrital albite or Ca-rich plagioclase grains that were subsequently dissolved or replaced by clay minerals, mainly illite. It appears that dissolution of detrital albite and $\mathrm{Ca}$-rich plagioclase grains led to substantial secondary porosity in the non-calcite cemented parts of the sandstones; even Kfeldspar shows partial dissolution and illitisation (Fig. 3D). However, subsequent compaction and growth of authigenic phases have reduced this secondary porosity (Fig. 3B). Furthermore, it is possible that the relatively high porosity in the lower parts of the sandstones originates from early precipitation of authigenic K-feldspar cement, which, similar to the detrital feldspars, was subsequently dissolved or replaced by illite resulting in major secondary porosity.

\section{Quartz diagenesis: stylolites, pressure solution and overgrowth}

Quartz cementation by development of stylolites, pressure solution between adjacent quartz grains and precipitation of macro-overgrowths are important in deeper $(3-5 \mathrm{~km})$ buried siliciclastic reservoirs (e.g. Bjørlykke et al. 1992; Worden \& Morad 2000). The investigated Upper Jurassic sediments are no exception, as detrital quartz grains are the major constituent of the Upper Jurassic sediments and quartz diagenesis is the major porosity-reducing feature outside the calcitecemented areas. However, parts of the sandstones show a high porosity and are without major quartz or calcite cement. The porosity is reduced by the formation of stylolites (Fig. 4A), pressure solution and by precipitation of quartz overgrowths (Fig. 4B, C); all late diagenetic processes that took place after authigenic K-feldspar precipitation, calcite cementation and feldspar dissolution and illitisation. The stylolites appear to have evolved from primary mica-rich and detrital clay-rich (mainly illitic) laminae (Fig. 4A).

Quartz pressure solution and stylolite formation may be related to the local microphysiochemical environment where alkaline conditions formed around clays, which could lead to enhanced pressure solution of quartz through increased solubility or an increased dissolution rate (Tada \& Siever 1989). Pressure solution has also been related to the surface charge of the illitic clays or mica (Walderhaug et al. 2006). Illitic clays are quite common in the investigated Upper Jurassic sandstones and may have led to enhanced development of stylolites. On the other hand, in sediments with high concentrations of clay and rock fragments, stylolites may be completely absent, due to the cushioning effect of the clay matrix and ductile lithic fragments (cf. Tada \& Siever 1989).

The pressure solution of detrital quartz grains and stylolite formation may have released silica for the quartz overgrowths. Syntaxial quartz overgrowths are found in all parts of the Upper Jurassic sediments except for the calcite-cemented areas.
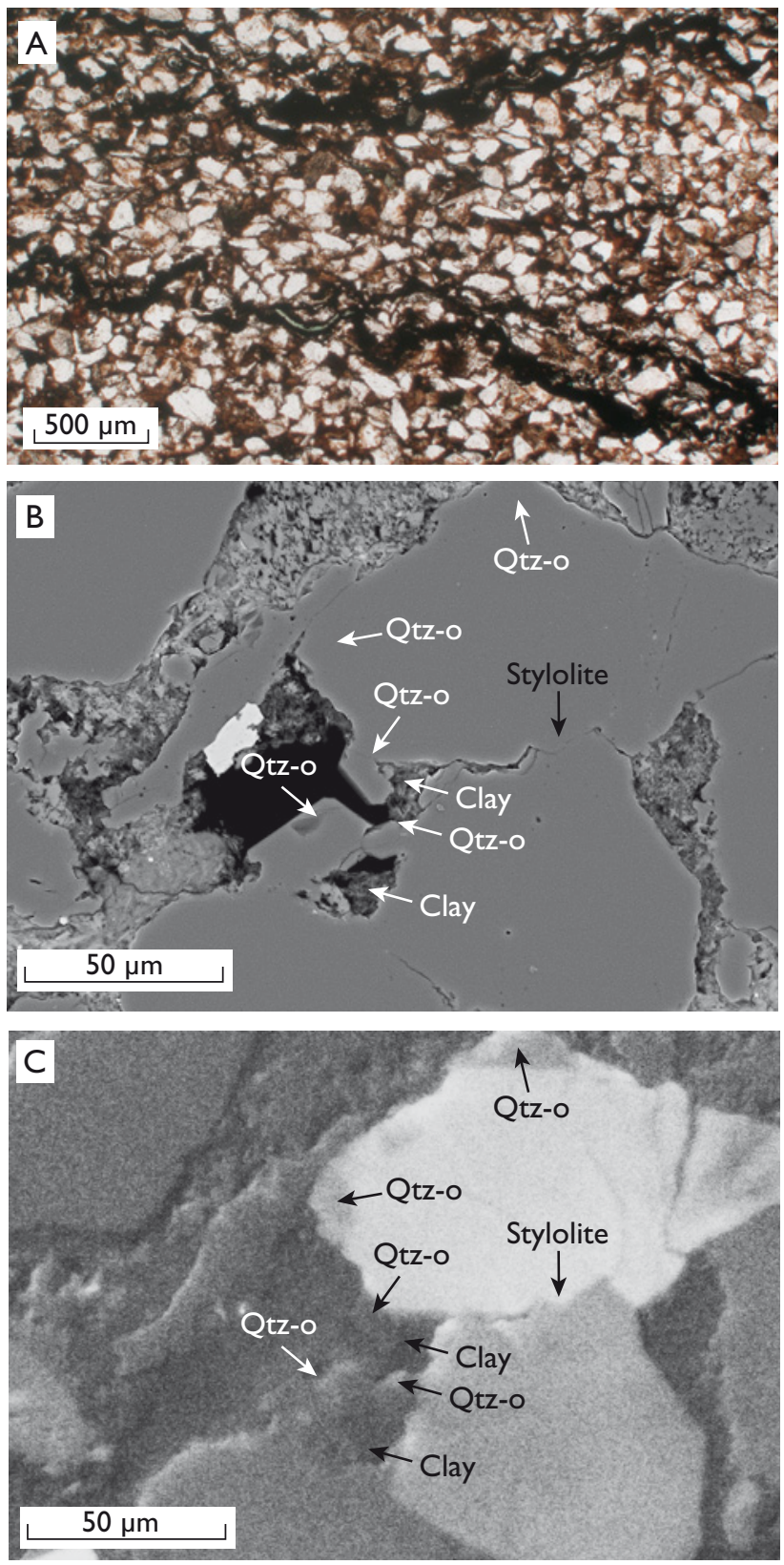

Fig. 4. Images showing development of quartz stylolites, quartz pressure solution and quartz overgrowths that are the main diagenetic features affecting the porosity outside the calcite-cemented parts of the sandstones. A: Quartz stylolite formation is enhanced by the presence of detrital clays and mica. Non-calcite cemented parts of the sandstones. Transmitted light microscope image. B: Quartz pressure solution between adjacent detrital quartz grains (black arrows) and quartz overgrowths (Qtz-o) that locally appear to be partly inhibited due to thick coatings of authigenic illite (white arrows). Non-calcite cemented sandstone. Back-scattered electron SEM image. C: Same area as Fig. 4B, but cathodoluminescence SEM image.

Peculiar, irregularly shaped quartz overgrowths are found in those parts of the sediments that show the highest present-day porosities (Fig. 4B, C). These peculiar quartz overgrowths 
can be interpreted as an indication of three completely different processes. They could either be caused by an incipient introduction of hydrocarbons, which partly covered the overgrowth (cf. Marchand et al. 2000). In other cases, it has been suggested that authigenic chlorite rims have inhibited or retarded quartz overgrowth (Aase et al. 1996). Aase \& Walderhaugh (2005) argued that the delay of such quartz precipitation was caused by thin coatings of micron-scale quartz crystals (microquartz). In sandstones of the Hejre-2 well abundant illite, formed during alteration of feldspar, may have inhibited pressure solution and stylolite formation, as a result of the cushioning effect of the clays, and furthermore have delayed the growth of authigenic quartz in the Upper Jurassic sediments.

\section{Summary and perspectives}

The quartz-rich Upper Jurassic reservoir sandstones in the Hejre-2 well are characterised by relatively high amounts of detrital K-feldspar, which most likely come from a volcanic source. Authigenic K-feldspar grew on detrital K-feldspar, perthite and albite grains and possibly Ca-rich plagioclase. The potassium for the K-feldspar overgrowths probably comes from marine pore fluids, detrital clay minerals and the underlying volcaniclastic conglomerates. The K-feldspar overgrowths were initially abundant, but were later dissolved except for the calcite-cemented parts of the sandstones. The formation of secondary porosity in the sandstones in the Hejre-2 well was mainly caused by dissolution of detrital feldspars and authigenic K-feldspar.

Quartz diagenesis prevails in the Upper Jurassic sediments in the Hejre-2 well where carbonates are absent and where illitic clays are restricted. Pressure solution and stylolite formation provide abundant silica, which is precipitated as quartz overgrowths. The presence of small amounts of illitic clays and mica may have enhanced the development of stylolites. On the other hand, relatively large amounts of illitic coatings seem to have inhibited or retarded the formation of quartz overgrowths, which otherwise could have reduced the porosity. Consequently, sandstone intervals in the Hejre-2 well with high porosities are the result of dissolution and illite replacement of detrital feldspars and early authigenic K-feldspar cement, thus secondary porosity was created; together with illite coatings that inhibited the formation of quartz overgrowths.

Future investigations may reveal whether the diagenetic evolution of Upper Jurassic sediments in other wells is similar to that encountered in the Hejre-2 well. Another aspect worth pursuing is to investigate if bulk rock geochemistry can be correlated with major diagenetic phenomena.

\section{Acknowledgement}

DONG Energy is thanked for permission to publish the present information on the Hejre- 2 well prior to public release of the data

\section{References}

Aase, N.E., Bjørkum, P.A. \& Nadeau, P.H. 1996: The effect of grain-coating microquartz on preservation of reservoir porosity. American Association of Petroleum Geologists Bulletin 80, 1654-1673.

Aase, N.E. \& Walderhaug, O. 2005: The effect of hydrocarbons on quartz cementation: diagenesis in the Upper Jurassic sandstone of the Miller Fields, North Sea, revisited. Petroleum Geoscience 11, 215-223.

Aghabawa, M.A. 1993: Petrology and geochemistry of the Rotliegendes volcanic rocks in Denmark and their tectonic implications. Dynmaisk/Stratigrafisk analyse af Palæozoikum i Danmark. EFP-89; område 1: Olie og Naturgas, 3, DGU Kunderapport 1993/35, $351 \mathrm{pp}$.

Bjørlykke, K., Nedkvitne, T., Ramm, M. \& Saigal, G.C. 1992: Diagenetic processes in the Brent Group (Middle Jurassic) reservoirs of the North Sea: an overview. In: Morton, A.C. et al. (eds): Geology of the Brent Group. Geological Society Special Publication (London) 61, 263-287.

Furnes, H., Elvsborg, A. \& Malm, O.A. 1982: Lower and Middle Jurassic alkaline magmatism in the Egersund sub-basin, North Sea. Marine Geology 46, 53-69.

Johannessen, P.N. 2003: Sedimentology and sequence stratigraphy of paralic and shallow marine Upper Jurassic sandstones in the northern Danish Central Graben. In: Ineson, J.R. \& Surlyk, F. (eds): The Jurassic of Denmark and Greenland. Geological Survey of Denmark and Greenland Bulletin 1, 367-402.

Lee, M.R. \& Parsons, I. 2003: Microtextures of authigenic Or-rich feldspar in the Upper Jurassic Humber Group, UK North Sea. Sedimentology $\mathbf{5 0}$, 597-608.

Marchand, A.M.E., Haszeldine, R.S., MacAulay, C.I., Swennen, R. \& Fallick, A.E. 2000: Quartz cementation inhibited by crestal oil charge: Miller deep water sandstone, UK North Sea. Clay Minerals 35, 201-210.

Michelsen, O., Nielsen, L.H., Johannessen, P.N. Andsbjerg, J. \& Surlyk, F. 2003: Jurassic lithostratigraphy and stratigrafic development onshore and offshore Denmark. In: Ineson, J.R. \& Surlyk, F. (eds): The Jurassic of Denmark and Greenland. Geological Survey of Denmark and Greenland Bulletin 1, 147-216.

Surdam, R.C., Boese, S.W. \& Crossey, L.J. 1984: The chemistry of secondary porosity. In: McDonald, D.A. \& Surdam, R.C. (eds): Clastic diagenesis. American Association of Petroleum Geologists Memoir 37, 127-149.

Tada, R. \& Siever, R. 1989: Pressure solution during diagenesis. Annual Review of Earth and Planetary Science 17, 89-118.

Walderhaug, O., Bjørkum, P.A. \& Aase, N.E. 2006: Kaolin-coating of stylolites, effect on quartz cementation and general implications for dissolutions at mineral interfaces. Journal of Sedimentary Research 76, 234-243.

Worden, R.H. \& Morad, S. 2000: Quartz cementation in oil field sandstones: a review of the key controversies. In: Worden, R.H. \& Morad, S. (eds): Quartz cementation in sandstones. Special Publication of the International Association of Sedimentologists 29, 1-20. Oxford: Blackwell Science. 